\title{
農村食飭の改善に関する研究 (1) \\ Studies on the Nutritional Improvement of the Farming Village Diets (Part 1)
}

\author{
大豆 加工 品 の 利 用 \\ Utilization and nutritional values of three soybean products
}

（昭和 38 年 4 月 30 日 受理）

佐 藤 德子武田みわ子

(Tokuko Sato) (Miwako Takeda)

\begin{abstract}
An experiment on the weanling rats was proceeded to estimate the nutritional value of three soybean products, "Miton", "Shinsei-tofu" and "Mame-no-hana".

The farming village diet in the Japanese Nutritional Survey was used as the control diet, in which animal protein (fish meal and skim milk) content is $33 \%$ of total protein. The low protein diet was prepared by excluding the animal protein from the above mentioned control diet.

Each soybean product was respectively added to the low protein diet to make the protein content as the control. About $40 \%$ of the total protein of these experimental diets was supplied from soybean.

Of the experimental animals, increasing rate of the body weight, weights of liver, spleen and kidney, efficiency ratio of diet and protein, lengths and weights of bones, calcification of bones, serum protein concentration, alkaline phosphatase activity and liver xanthine oxidase activity were estimated for the indication of the nutritional values of these diets.

The followings were concluded from the experiment. The low protein diets revealed the lowest nutritional value. However, the three diets containing each of three soybean products showed almost the same value and also had a higher nutritional value compared with the control and skim milk diets.
\end{abstract}

東北地方農村が特に米食偏重で良質蛋白，灰分および ビタミンなどに不足し，住民の健康·体力に悪影響を及ほ している事実はすでに多くの研究者により指適されてい る12)。またその食生活改善のためには種々の手段が実 施され着々成果をあげている3゙。一方比較的良質蛋白源 として早くからその価値が認められ，不足する蛋白の給 源食品として利用されている大豆扣よびその製品の栄養 価についても従来多くの研究() 屃が行なわれ林(4)らは大 豆の栄荃価はその加工処理に影響されると述へてている。 最近新しい大豆加工品が出廻ってきたが，それぞれの製 法については詳細を知り得ない場合すあってその栄養価 については疑閭の点がある。最近市眅されている 3 種の 大豆加工食品を蛋白補給源として農村食慨に添加した場 合の効果を知る目的で ratによる動物実験を行なった。

\section{実 験 方 法}

1. 実験動物：可及的に同日に出産するように標準飼
料で飼育したWister 系の親 rat 2 腹より生まれた子 rat $50 \mathrm{~g}$ 前後のわのを, 乱塊法により雌雄 2 匹ずつ 4 匹 を 1 群とし， 6 群合計 24 匹を用いた。

2. 試験食品：試験しようとする新大豆加工食品はミ 一トン, 新生豆腐および豆の花(いずれも商品名)の 3 種 で各会社による成分表は表 1 打よび因 1 に示す。いずれ

図 1
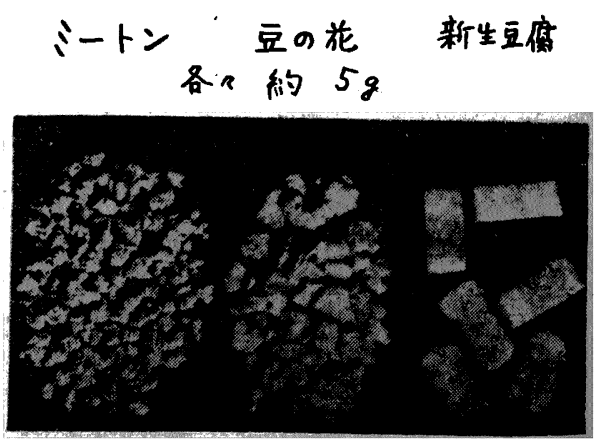
第 16 巻 第 4 号

表 1 供試食品の分析値 (100 g 中)

（商品パンフレットによる）

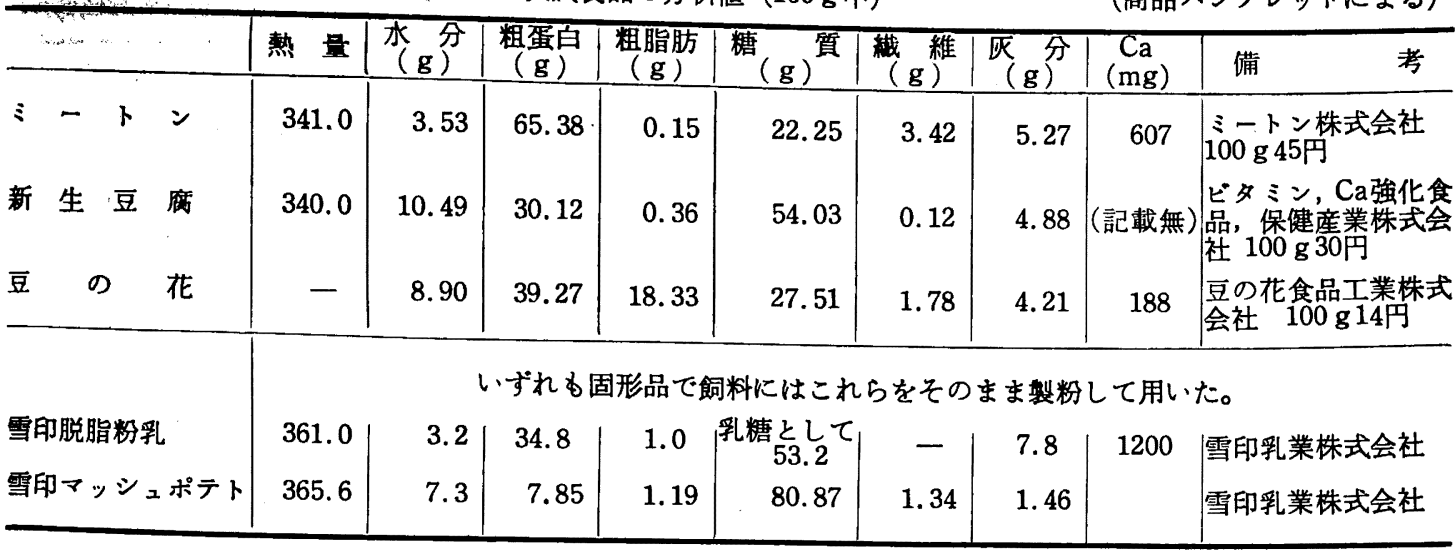

表 2 基本飼料組成（計算値）

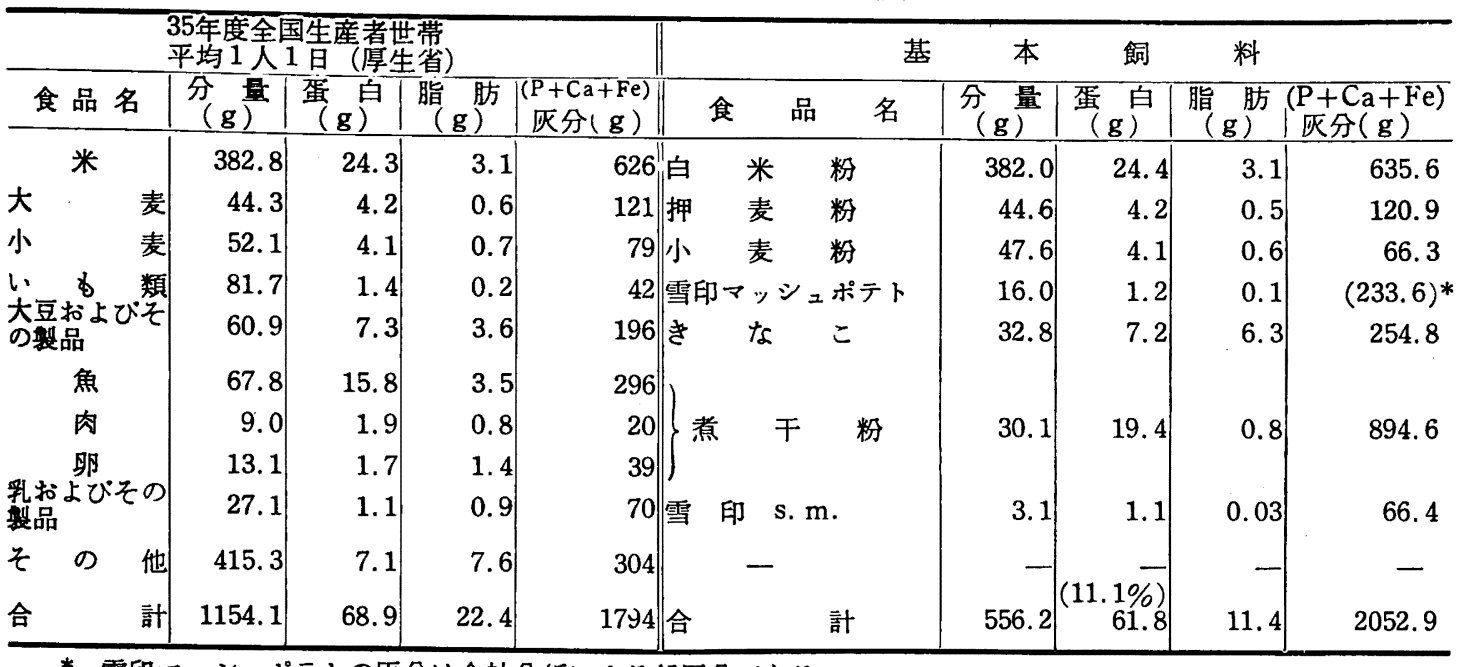

* 雪印マッシュポテトの灰分は会社分析による総灰分である。

表 3 試 験 飼 料 食品組 成

\begin{tabular}{|c|c|c|c|c|c|c|c|c|c|c|c|c|}
\hline 試験区 & 白米粉 & 押麦粉 & 小麦粉 & 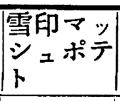 & きなこ & 㶨干粉 & $\begin{array}{l}\text { 雪印 } \\
\text { s.m. }\end{array}$ & $\Sigma-r$ & $\begin{array}{l}\text { 新生豆 } \\
\text { 萑 }\end{array}$ & 豆の花 & s.m. & 合計 \\
\hline 基 本 食 群 & 382.0 & 44.6 & 47.6 & 16.0 & 32.8 & 30.1 & 3.1 & - & - & - & - & 556.2 \\
\hline 低 蛋 白 群 & 415.0 & 44.6 & 47.6 & 16.0 & 32.8 & - & - & - & - & - & - & 556.0 \\
\hline ミートン群(1) & 375.0 & 44.6 & 47.6 & 16.0 & 32.8 & - & - & 40.0 & - & - & - & 556.0 \\
\hline 新 生 豆 腐 群(2) & 320.0 & 44.6 & 47.6 & 16.0 & 32.8 & - & - & 一 & 95.0 & - & - & 556.0 \\
\hline 豆 の 花 群(3) & 340.0 & 44.6 & 47.6 & 16.0 & 32.8 & - & - & - & 一 & 75.0 & - & 556.0 \\
\hline s. $\mathrm{m}$. & 335.0 & 44.6 & 47.6 & 16.0 & 32.8 & - & - & - & - & - & 80.0 & 556.0 \\
\hline
\end{tabular}

（1）ミートンはミートン株式会社の固型食品を粉末とした。

(2) 新生豆属は保健産䅈株式会社のホサン新生豆腐（固型）を粉末とした。

(3) 豆の花食品工業株式会社の製品を粉末とした。 
も固形食品でミートンについては稲垣ら゙がその製法を 述べているが，新生豆腐，豆の花については明らかでな いが新生豆腐には Ca が強化してあることが明記してあ り, 豆の花は外観が従来の「打ち豆」に類似した食品で

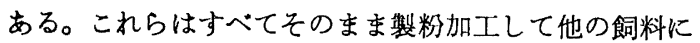
混入して用いた。

3. 基本および試験飼料：厚生省国民栄盖調査成績昭 和35年度の生産世帯の平均摄取食品構成とほほ同じにな るように該当する主な蛋白給源食品を配合したものを基 本飼料とし 1 群とす。該当食品の配合は表 2 に示す通り で蛋白含有率は計算值 $11.1 \%$, 動蛋比は33\%となる。基 本飼料の中, 穀類, いも類，みそなどの食品のみより構 成される食餌 (東北地方農村食餌の約 $2 / 3^{3}{ }^{8)}$ 占め, 米飯 みそ汁を主とする食慨に相当し蛋白含有率は計算值 7.7 \%）を 2 群の低蛋白食とした。低蛋白食に基本食と蛋白 含有量がほぼ同じになるよ5にそれぞれ，ミートン（3 群), 新生豆腐 (4 群), 豆の花 (5 群) および比較のた め脱脂粉乳（6群）を加えたものを試験食とし合計 6 群 とした。基本および試験飼料の食品構成は表 3 に，栄盖 組成の計算値扣よび実測値は表 4 に, 給源食品別蛋白摂 取割合は表 5 に示す通りで， $3,4,5,6$ 各試験食群の 添加食品による蛋白添加量は全蛋白の約 $40 \%$ を占める。 なお各群に脂肪, 灰分およびビタミンを補給するため,大 豆油を飼料 $100 \mathrm{~g}$ につき $3 \mathrm{~g} \mathrm{McCollum-Simmonds}$ 合塩を飼料 $100 \mathrm{~g}$ につき $2 \mathrm{~g}$ 打よび強力ビタベビーを飼 料 $10 \mathrm{~g}$ 当り約 $25 \mathrm{mg}$ を混入した。混合塩扰よびビタミン 斉の成分組成は表 6-(1),(2) に示す。

4. 実験期間 : 1962年 7 月12日より 8 月 20 日までの約
表 5 給源食品別蛋白摂取割合（計算値\%)·

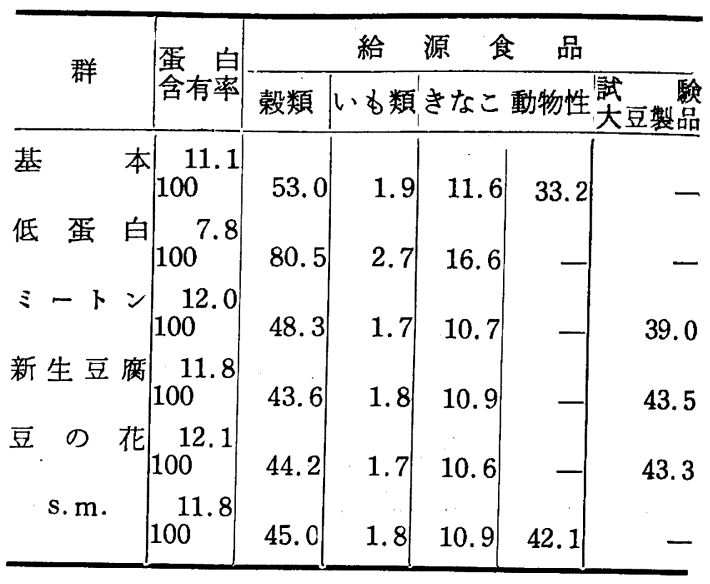

表 6-(1) McCollum-Simmonds塩

\begin{tabular}{|c|c|c|}
\hline 成 & 分 & 含有量 $(\mathrm{g}$ ) \\
\hline 食塩 & $\mathrm{NaCl}$ & 17.3 \\
\hline 酸性燐酸ソーダ & $\mathrm{NaH}_{2} \mathrm{PO}_{4} \cdot \mathrm{H}_{2} \mathrm{O}$ & 34.7 \\
\hline 燐 酸 カ リ & $\mathrm{K}_{2} \mathrm{HPO}_{4}$ & 95.4 \\
\hline " カルシウム & $\mathrm{CaH}_{4}\left(\mathrm{PO}_{4}\right)_{2} \cdot \mathrm{H}_{2} \mathrm{O}$ & 54.0 \\
\hline クエン酸 鉄 & $\mathrm{Fe}\left(\mathrm{C}_{6} \mathrm{H}_{5} \mathrm{O}_{7}\right)$ & 11.8 \\
\hline 乳 酸 石 灰 & $\mathrm{Ca}\left(\mathrm{C}_{3} \mathrm{H}_{5} \mathrm{O}_{3}\right)_{2}$ & $139.0 \sim 130.0$ \\
\hline 硫酸苦土（無水） & $\mathrm{MgSO}_{4}$ & 26.2 \\
\hline 沃 化 カ リ & $\mathrm{KI}$ & $3 \sim 3.7$ \\
\hline 合 & & $372.4 \sim 382.1$ \\
\hline
\end{tabular}

以上のよ5に配合混合したすのを䬣料 $100 \mathrm{~g}$ にっき $2 \mathrm{~g}$ 混合

表 4 試 験 飼 料 栄養 組 成

(100 g 中)

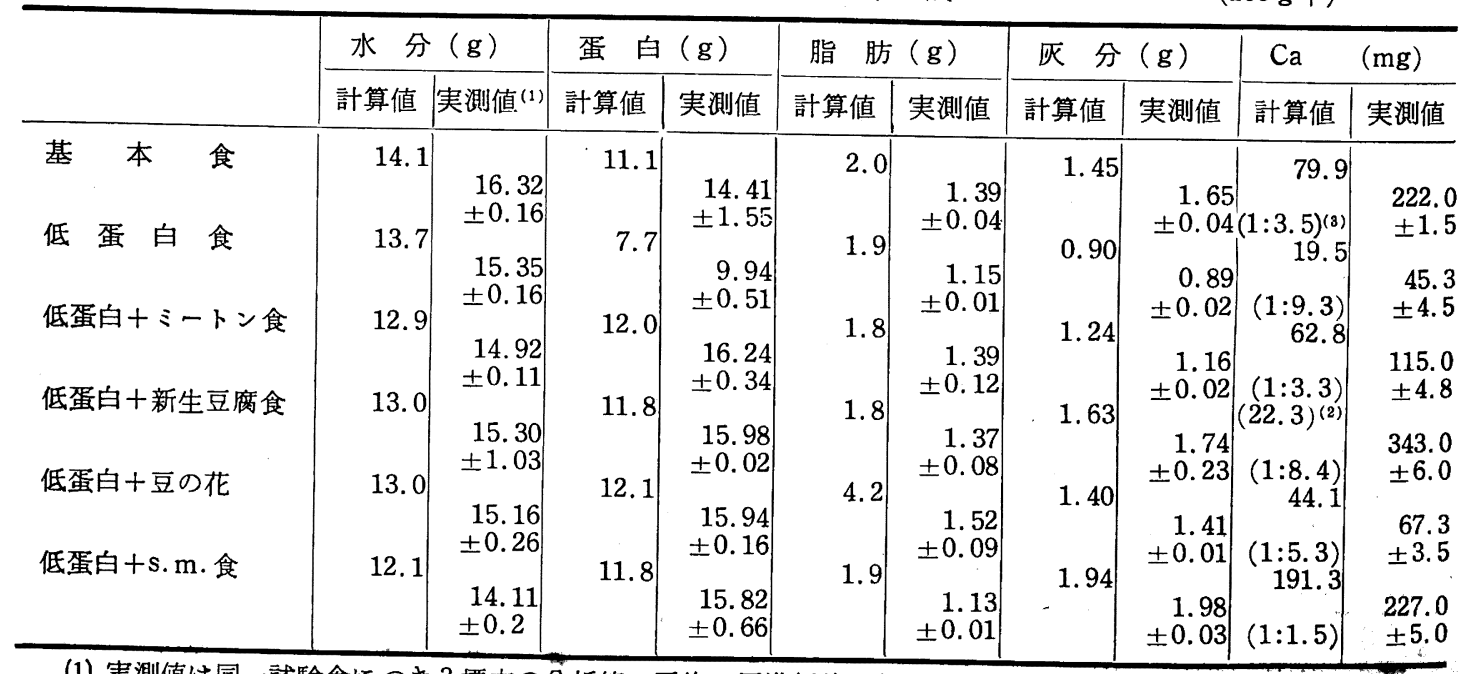

(1) 実測値は同一試験食につき 3 標本の分析値の平均と標準偏差である。

(2) 新生豆腐は商品としてCa分析值がないので添加新生豆腐分を除いた分の值である。

(3) $\mathrm{Ca}: \mathrm{P}$ の比を示す。 
表6-(2) ビタミン剤（強力ビタべビー） 3 tablets $(0.6 \sim 0.7 \mathrm{~g})$ 中

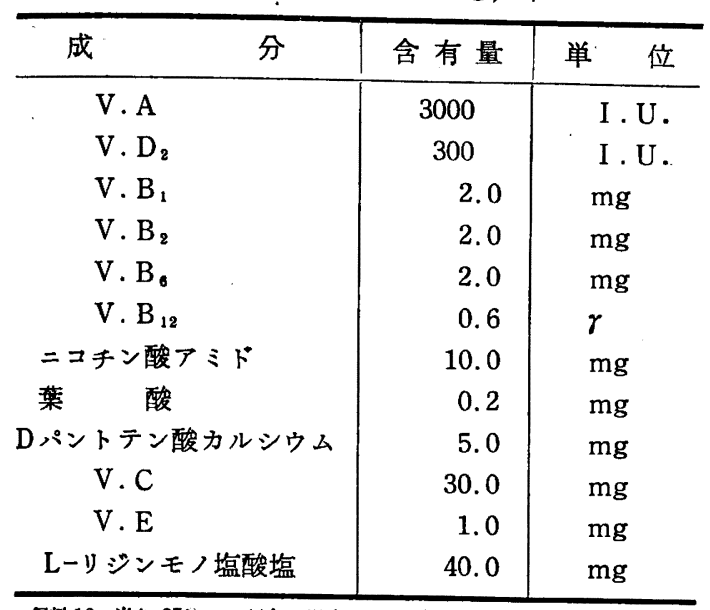

鸼料 $10 \mathrm{~g}$ 当り $25 \mathrm{mg}$ の割合に混合。 1 tablet は約 $0.2 \mathrm{~g}$ 40日間である。

5. 飼育方法および測定項目：rat は金あみの籠に 2 匹ずつ!同性)入れ，籠の底に布を張ったバットを打き毎 日の残慨を霬尿などより区別して採集しやすいよ5にし た。

（1）撕取飼料：各食慨は 1 日 1 匹10 $25 \mathrm{~g}$ (食べ残す程 度)を, 混合塩, ビタミンおよび大豆油と共に混合し一 定量の水で団子状にまとめ, 約15分蒸してから放冷し, 食べ易い大きさに分けて毎日一定時刻(午後 1 時〜 3 時) に投与した。水は自由に水道水を与えた。翌日飼料投与 直前，残慨を集めて秤量し，乾物に換算し投与飼料との

因2 体重增加曲線（各群 9 o 合計 4 匹の平均値）

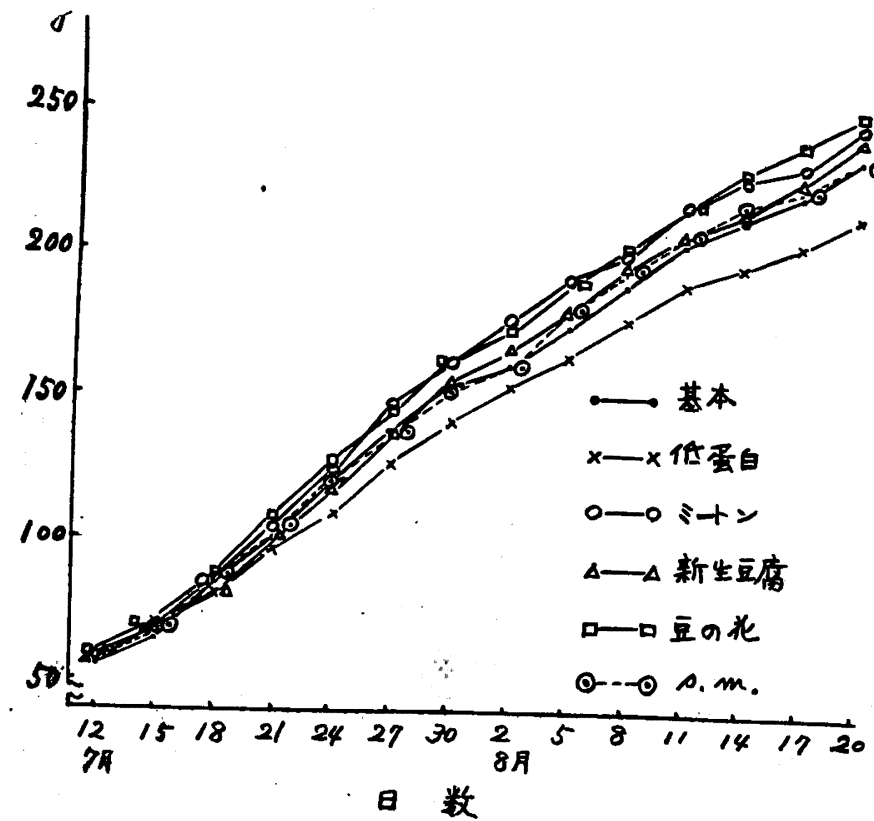

差を摄取飼料とした。

（2）体重測定：体重は 3 日目毎に，飼料投与前11時 12時に測定し, 初重と終重との差を体重增加量とし, 初 重 $1 \mathrm{~g}$ 当りの増加量を体重增加率とした。また体重增加 量 $1 \mathrm{~g}$ 当りの摂取飼料量を飼料効率とした。

(3) 解剖怙よび測定：試験終了後, 漸首により採血し 血清アルカリフォスファターゼ活性度（以下Al ・ P-ase A。とする）および血清蛋白を測定した。その後解剖して 症状を観察し, 肝臓, 腎臓扣よび脾臓の重量を測定し, 肝 臟については Xanthine Oxidase Activity（以下X. O.A.とする）を測定した。血清 $\mathrm{Al} \cdot \mathrm{P}$-ase A. は中 $川^{9)}$ 法により, 血清蛋白は日立蛋白計により, 肝 X. O .

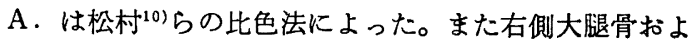
び陘骨・腓骨について骨重量，骨灰分捛よび骨 Ca 量を 常法により測定した。

\section{実 験 結 果}

（1）体重增加率：各群 4 匹の平均体重增加曲線は図 2 に示す通りで, 初重に於いては豆の花, 低蛋白, s. m., ミートン, 新生豆腐, 基本の各群の順に大であるが, 終 了時体重は豆の花, ミートン, 新生豆腐と 3 大豆加工食 品群が上位を占め基本群, s.m. 群がこれにつぎ，低蛋 白群が最下位となっている。体重增加率は表 7 のよ5で 低蛋白群が最も小であるが群別の平均值に有意差が認め られず，性別には雄は踓より $(\mathrm{P}<0.01)$ また腹別では 1 は 2 より $(\mathrm{P}<0.001)$ それぞれ有意差で大であった。

（2）飼料効率打よび蛋白效率：共に表 7 に示す通りで 分散分析すると, 飼料効率では群別の差に有 意性が認められないが, 性別には雌が雄より 有意差 $(P<0.05)$ で大である。すなわち体 重 $1 \mathrm{~g}$ 增加するに要する飼料量が大となり飼 料効率は悪い。摂取蛋白 $1 \mathrm{~g}$ 当りの体重增加 量を蛋白効率とすると，群別にも性別にも有 意差が認められ，低蛋白群は他のすべての群 上り大である(基本群との差 $\mathrm{P}<0.05,3$ 大豆 製品群扰よびs.m. 群との差 $\mathrm{P}<0.01)$ 。また 性別には雄が雙より（P<0.05）大である。

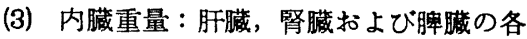
測定值拉よびそれらの合計值についてい表 8 に示す通りで，個々の測定值について同様の 傾向が見られる。すなわち低蛋白群が最す小 さく基本群がこれにつぎ, 新生豆度, 豆の花 および s.m.の各群が同様の価でこれにつぎ， ミートン群が最も大である。肝と堅につい ては群別にも性別にも平均値に有意差が認め られるが脾には有意差は認められない。3内 
栄甆と食鋉

表 7 体重堌加率

\begin{tabular}{|c|c|c|c|c|c|c|c|c|c|c|c|c|c|c|}
\hline & 群 & 性 & 腹 & ( $\mathrm{g})^{\text {重 }}$ & 終 $(\mathrm{g}){ }^{\text {重 }}$ & $\begin{array}{c}\text { 増加量 } \\
(\mathrm{g})\end{array}$ & 增加 & 摔 & \begin{tabular}{|l|}
40 日 2 元 \\
分摄取餇 \\
料量 $(\mathrm{g})$
\end{tabular} & 飼料 & 効率 & $\begin{array}{l}40 \text { 日 } 2 \text { 元 } \\
\text { 分蛋白摂 } \\
\end{array}$ & 蛋白 & 効率 \\
\hline 1 & 基 & $\begin{array}{l}\delta \\
\text { 우 }\end{array}$ & $\begin{array}{ll}1 & \\
1 & 2 \\
& 2\end{array}$ & $\begin{array}{l}54.3 \\
52.3 \\
55.5 \\
62.5\end{array}$ & $\begin{array}{l}267.0 \\
240.0 \\
215.0 \\
220.0\end{array}$ & $\begin{array}{l}212.7 \\
187.7 \\
159.5 \\
157.5\end{array}$ & 3. 22 & $\begin{array}{l}3.9 \\
3.6 \\
2.9 \\
2.5\end{array}$ & $\begin{array}{r}1361.3 \\
1195.8\end{array}$ & 3.6 & $\begin{array}{l}3.4 \\
3.8\end{array}$ & $\begin{array}{l}196.0 \\
172.1\end{array}$ & 1.94 & $\begin{array}{l}2.04 \\
1.84\end{array}$ \\
\hline 2 & 低 蛋 白 & $\begin{array}{l}\delta \\
\text { o }\end{array}$ & $\begin{array}{ll}1 & \\
1 & 2 \\
& 2\end{array}$ & $\begin{array}{l}48.6 \\
81.0 \\
46.3 \\
64.0\end{array}$ & $\begin{array}{l}175.0 \\
258.0 \\
205.0 \\
222.0\end{array}$ & $\begin{array}{l}126.4 \\
177.0 \\
158.7 \\
158.0\end{array}$ & 2.66 & $\begin{array}{l}2.6 \\
2.2 \\
3.4 \\
2.5\end{array}$ & $\begin{array}{l}1242.4 \\
1241.0\end{array}$ & 4.0 & $\begin{array}{l}4.1 \\
3.9\end{array}$ & $\begin{array}{l}122.9 \\
122.8\end{array}$ & 2.51 & $\begin{array}{l}2.46 \\
2.57\end{array}$ \\
\hline 3 & $\Sigma-ト ン$ & $\begin{array}{l}\delta \\
q\end{array}$ & $\begin{array}{ll}1 & \\
1 & 2 \\
& 2\end{array}$ & $\begin{array}{l}49.2 \\
71.0 \\
48.5 \\
64.0\end{array}$ & $\begin{array}{l}263.0 \\
300.0 \\
206.0 \\
215.0\end{array}$ & $\begin{array}{l}213.8 \\
229.0 \\
157.5 \\
151.0\end{array}$ & 3.28 & $\begin{array}{l}4.3 \\
3.2 \\
3.2 \\
2.4\end{array}$ & $\begin{array}{l}1419.0 \\
1208.4\end{array}$ & 3.5 & $\begin{array}{l}3.2 \\
3.9\end{array}$ & $\begin{array}{l}229.8 \\
195.7\end{array}$ & 1.74 & $\begin{array}{l}1.92 \\
1.57\end{array}$ \\
\hline 4 & 新生豆 腐 & $\begin{array}{l}\hat{o} \\
\text { ㅇ }\end{array}$ & $\begin{array}{ll}1 & \\
1 & 2 \\
& 2\end{array}$ & $\begin{array}{l}41.5 \\
74.2 \\
47.2 \\
65.4\end{array}$ & $\begin{array}{l}219.0 \\
320.0 \\
180.0 \\
245.0\end{array}$ & $\begin{array}{l}177.5 \\
245.8 \\
132.8 \\
179.6\end{array}$ & $3.28 \stackrel{3}{2}$ & $\begin{array}{l}4.3 \\
3.3 \\
2.8 \\
2.7\end{array}$ & $\begin{array}{r}1405.0 \\
1221.9\end{array}$ & & $\begin{array}{l}3.3 \\
3.9\end{array}$ & $\begin{array}{r}223.3 \\
194.2\end{array}$ & 1.74 & $\begin{array}{l}1.89 \\
1.60\end{array}$ \\
\hline 5 & 豆 & $\begin{array}{l}\hat{o} \\
\text { 우 }\end{array}$ & $\begin{array}{ll}1 & \\
1 & 2 \\
& 2\end{array}$ & $\begin{array}{l}41.2 \\
87.0 \\
46.4 \\
66.0\end{array}$ & $\begin{array}{l}216.0 \\
345.0 \\
196.0 \\
245.0\end{array}$ & $\begin{array}{l}174.8 \\
258.0 \\
149.6 \\
179.0\end{array}$ & 3.28 & \begin{tabular}{l|}
4.2 \\
3.0 \\
3.2 \\
2.7
\end{tabular} & $\begin{array}{l}1393.6 \\
1200.8\end{array}$ & & $\begin{array}{l}3.2 \\
3.7\end{array}$ & $\begin{array}{l}221.5 \\
190.9\end{array}$ & 1.83 & $\begin{array}{l}1.95 \\
1.72\end{array}$ \\
\hline 6 & 脱 脂 粉 乳 & o & $\begin{array}{ll}1 & \\
1 & 2 \\
& 2\end{array}$ & $\begin{array}{l}49.5 \\
78.7 \\
36.2 \\
59.6\end{array}$ & $\begin{array}{l}245.0 \\
318.0 \\
173.0 \\
200.0\end{array}$ & $\begin{array}{l}195.5 \\
239.3 \\
136.8 \\
140.4\end{array}$ & $.27 \begin{array}{r}3 \\
3 \\
2\end{array}$ & \begin{tabular}{l|}
3.9 \\
3.0 \\
3.8 \\
2.4
\end{tabular} & $\begin{array}{c}1391.6 \\
1074.4\end{array}$ & & $\begin{array}{l}3.2 \\
3.9\end{array}$ & $\begin{array}{l}219.8 \\
169.7\end{array}$ & 1.80 & $\begin{array}{l}1.97 \\
1.63\end{array}$ \\
\hline
\end{tabular}

* 各群の平均値

\begin{tabular}{|c|c|c|c|c|c|c|c|c|c|c|c|}
\hline & 群 & 性 & 腹 & $* \frac{\overline{\text { F }}}{\mathrm{X}} \pm$ & $\begin{array}{l}\text { 蔵 } \\
\text {. L. }\end{array}$ & & $\begin{array}{l}\text { 臓 } \\
\end{array}$ & & $\begin{array}{l}\text { 蔵 } \\
\text {. L. }\end{array}$ & & $\begin{array}{l}\text { 目十脾 } \\
\text { E. L. }\end{array}$ \\
\hline 1 & 基 & $\begin{array}{l}\hat{\delta} \\
\text { o }\end{array}$ & $\begin{array}{ll}1 & \\
1 & 2 \\
& 2\end{array}$ & $\begin{array}{l}9.1 \\
8.2 \\
9.7 \\
7.4\end{array}$ & $\begin{array}{l}8.6^{(\mathrm{g})} \\
\pm 1.6\end{array}$ & $\begin{array}{l}1.6 \\
1.4 \\
1.8 \\
1.3\end{array}$ & $\begin{array}{l}1.5^{(\mathrm{g})} \\
\pm 0.3\end{array}$ & $\begin{array}{l}1.1 \\
0.8 \\
0.9 \\
1.2\end{array}$ & $\begin{array}{l}1.0^{(\mathrm{g})} \\
\pm 0.2\end{array}$ & $\begin{array}{r}11.8 \\
10.4 \\
12.4 \\
9.9\end{array}$ & $\begin{array}{l}\text { 11. } \\
\quad \pm 1.8\end{array}$ \\
\hline 2 & 低 蛋 白 & $\begin{array}{l}\delta \\
q\end{array}$ & $\begin{array}{ll}1 & \\
& 2 \\
1 & \\
& 2\end{array}$ & $\begin{array}{l}5.9 \\
8.3 \\
6.8 \\
8.2\end{array}$ & $\begin{array}{l}7.3 \\
\pm 1.8\end{array}$ & $\begin{array}{l}1.7 \\
1.4 \\
1.4 \\
1.2\end{array}$ & $\begin{array}{l}1.4 \\
\pm 0.3\end{array}$ & $\begin{array}{l}0.7 \\
1.1 \\
0.6 \\
0.9\end{array}$ & $\begin{array}{l}0.8 \\
\pm 0.3\end{array}$ & $\begin{array}{r}8.3 \\
10.8 \\
8.8 \\
10.3\end{array}$ & $\begin{array}{l}9.5 \\
\pm 1.8\end{array}$ \\
\hline 3 & 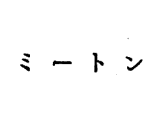 & o & $\begin{array}{ll}1 & \\
& 2 \\
1 & \\
& 2\end{array}$ & $\begin{array}{r}11.1 \\
10.7 \\
8.1 \\
8.3\end{array}$ & $\begin{array}{l}9.5 \\
\quad \pm 2.7\end{array}$ & $\begin{array}{l}1.8 \\
1.9 \\
1.5 \\
1.2\end{array}$ & $\begin{array}{l}1.6 \\
\pm 0.5\end{array}$ & $\begin{array}{l}1.2 \\
1.2 \\
1.0 \\
1.2\end{array}$ & $\begin{array}{l}1.1 \\
\pm 0.1\end{array}$ & $\begin{array}{l}14.1 \\
13.8 \\
10.6 \\
10.7\end{array}$ & $\begin{array}{l}12.3 \\
\pm 3.0\end{array}$ \\
\hline 4 & 新生豆腐 & $\begin{array}{l}\hat{\delta} \\
\text { 우 }\end{array}$ & $\begin{array}{ll}1 & \\
& 2 \\
1 & \\
& 2\end{array}$ & $\begin{array}{l}7.5 \\
9.5 \\
5.9 \\
7.8\end{array}$ & $\begin{array}{l}7.6 \\
\pm 2.3\end{array}$ & $\begin{array}{l}1.3 \\
1.8 \\
1.0 \\
1.2\end{array}$ & $\begin{array}{l}1.3 \\
\pm 0.5\end{array}$ & $\begin{array}{l}0.7 \\
1.0 \\
1.0 \\
1.1\end{array}$ & $\begin{array}{l}0.9 \\
\pm 0.2\end{array}$ & $\begin{array}{r}9.5 \\
12.3 \\
7.9 \\
10.1\end{array}$ & $\begin{array}{l}9.9 \\
\pm 2.8\end{array}$ \\
\hline 5 & 豆 の 花 & ô & $\begin{array}{ll}1 & \\
1 & 2 \\
& 2\end{array}$ & $\begin{array}{r}7.4 \\
10.6 \\
6.3 \\
7.1\end{array}$ & $\begin{array}{l}7.8 \\
\pm 3.0\end{array}$ & $\begin{array}{l}1.6 \\
2.0 \\
1.2 \\
1.4\end{array}$ & $\begin{array}{l}1.5 \\
\pm 0.5\end{array}$ & $\begin{array}{l}1.1 \\
1.5 \\
0.8 \\
0.8\end{array}$ & $\begin{array}{l}1.0 \\
\pm 0.5\end{array}$ & $\begin{array}{r}10.1 \\
14.1 \\
8.3 \\
9.3\end{array}$ & $\begin{array}{l}10.4 \\
\pm 4.0\end{array}$ \\
\hline 6 & 脱脂粉乳 & $\begin{array}{l}\delta \\
\text { o }\end{array}$ & $\begin{array}{ll}1 & \\
& 2 \\
1 & \\
& 2\end{array}$ & $\begin{array}{r}8.3 \\
10.3 \\
5.8 \\
6.2\end{array}$ & $\begin{array}{l}7.6 \\
\pm 3.3\end{array}$ & $\begin{array}{l}1.4 \\
1.9 \\
1.0 \\
1.2\end{array}$ & $\begin{array}{l}1.3 \\
\pm 0.6\end{array}$ & $\begin{array}{l}0.9 \\
1.0 \\
0.9 \\
1.0\end{array}$ & $\begin{array}{l}0.9 \\
\pm 0.0\end{array}$ & $\begin{array}{r}10.6 \\
13.2 \\
7.7 \\
8.4\end{array}$ & $\begin{array}{l}9.9 \\
\pm 3.9\end{array}$ \\
\hline
\end{tabular}

\footnotetext{
* $\overline{\mathrm{X}} \pm$ F . L. は平均值 $\pm 95 \%$ 信頼限界
} 
第 16 巻 第 4 号

表 9 骨成分 (大腿骨および脛骨と腓骨)

\begin{tabular}{|c|c|c|c|c|c|c|c|}
\hline \multicolumn{2}{|c|}{ 群 別 } & \multicolumn{2}{|c|}{ 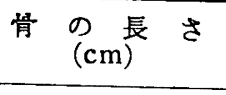 } & \multicolumn{2}{|c|}{ 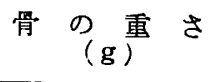 } & \multicolumn{2}{|c|}{ 骨 Ca / 骨 重 } \\
\hline 1 & 基 & $\begin{array}{l}6.8 \\
6.5 \\
7.0 \\
6.4 \\
\end{array}$ & $\begin{array}{l}* \\
6.4 \\
\pm 0.4\end{array}$ & $\begin{array}{l}1.4 \\
1.0 \\
1.2 \\
1.1\end{array}$ & $\begin{array}{l}1.1 \\
\pm 0.2 \\
\end{array}$ & $\begin{array}{l}1.3 \\
3.1 \\
3.3 \\
2.0 \\
\end{array}$ & $\begin{array}{l}2.4 \\
\pm 1.5 \\
\end{array}$ \\
\hline 2 & 低 㔻 白 & $\begin{array}{l}5.7 \\
6.8 \\
6.1 \\
6.3 \\
\end{array}$ & $\begin{array}{l}6.2 \\
\pm 0.7 \\
\end{array}$ & $\begin{array}{l}0.9 \\
1.4 \\
0.8 \\
1.0 \\
\end{array}$ & $\begin{array}{l}1.0 \\
\pm 0.4\end{array}$ & $\begin{array}{l}3.3 \\
1.6 \\
2.6 \\
2.3\end{array}$ & $\begin{array}{l}2.4 \\
\pm 1.1 \\
\end{array}$ \\
\hline 3 & $\Sigma-ト \nu$ & $\begin{array}{l}6.7 \\
7.1 \\
6.4 \\
7.9 \\
\end{array}$ & $\begin{array}{l}7.0 \\
\pm 1.0 \\
\end{array}$ & $\begin{array}{l}1.4 \\
1.3 \\
1.1 \\
1.2 \\
\end{array}$ & $\begin{array}{l}1.2 \\
\pm 0.1 \\
\end{array}$ & $\begin{array}{l}3.0 \\
2.0 \\
1.9 \\
2.7 \\
\end{array}$ & $\begin{array}{l}2.4 \\
\pm 0.8\end{array}$ \\
\hline 4 & 新 生 豆 腐 & $\begin{array}{l}6.6 \\
7.9 \\
6.3 \\
6.5 \\
\end{array}$ & $\begin{array}{l}6.8 \\
\pm 1.1 \\
\end{array}$ & $\begin{array}{l}1.2 \\
1.3 \\
0.9 \\
1.2 \\
\end{array}$ & $\begin{array}{l}1.1 \\
\pm 0.2\end{array}$ & $\begin{array}{l}3.8 \\
5.3 \\
4.7 \\
4.2 \\
\end{array}$ & $\begin{array}{l}4.5 \\
\pm 1.0 \\
\end{array}$ \\
\hline & 豆 の 花 & $\begin{array}{l}6.6 \\
7.5 \\
6.4 \\
6.6 \\
\end{array}$ & $\begin{array}{l}6.7 \\
\pm 0.7 \\
\end{array}$ & $\begin{array}{l}1.2 \\
1.5 \\
1.1 \\
1.1 \\
\end{array}$ & $\begin{array}{l}1.2 \\
\pm 0.2 \\
\end{array}$ & $\begin{array}{l}1.8 \\
3.1 \\
3.4 \\
5.0 \\
\end{array}$ & $\begin{array}{l}3.3 \\
\pm 2.0 \\
\end{array}$ \\
\hline 6 & s. m. & $\begin{array}{l}6.6 \\
7.4 \\
6.4 \\
6.9 \\
\end{array}$ & $\begin{array}{l}6.8 \\
\pm 0.6\end{array}$ & $\begin{array}{l}1.2 \\
1.6 \\
1.0 \\
1.2 \\
\end{array}$ & $\begin{array}{l}1.2 \\
\pm 0.3\end{array}$ & $\begin{array}{l}2.3 \\
3.5 \\
3.4 \\
3.8\end{array}$ & $\begin{array}{l}3.2 \\
\pm 1.0\end{array}$ \\
\hline
\end{tabular}

表10 血清蛋白, 血清Al·P-ase, 怙よび肝X. O-ase 活性度

\begin{tabular}{|c|c|c|c|c|c|c|c|c|c|c|c|c|}
\hline \multicolumn{3}{|c|}{ 群 } & \multirow{2}{*}{$\begin{array}{l}\text { 別 } \\
\text { 本 }\end{array}$} & \multirow{2}{*}{\begin{tabular}{|c|} 
性 別 \\
\multirow{2}{*}{} \\
\end{tabular}} & \multirow[b]{2}{*}{$\begin{array}{l}1 \\
1\end{array}$} & \multirow{2}{*}{$\begin{array}{l}\text { 別 } \\
2 \\
2\end{array}$} & \multirow{2}{*}{$\begin{array}{l}\text { 血 } \\
5.8 \\
6.3 \\
6.0 \\
5.9\end{array}$} & \multirow{2}{*}{ 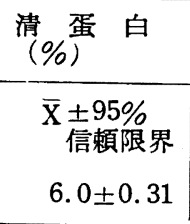 } & \multicolumn{2}{|c|}{$\begin{array}{c}\text { 血清Al·P-ase活性度 } \\
(\mathrm{mM} / \mathrm{h} / \mathrm{l})\end{array}$} & \multicolumn{2}{|c|}{$\underset{(\mu l / \mathrm{h} / \mathrm{g})}{\operatorname{Af} X}$} \\
\hline 1 & 基 & & & & & & & & $\begin{array}{l}7.6 \\
9.6 \\
7.2 \\
6.6\end{array}$ & $7.75 \pm 2.06$ & $\begin{array}{l}405 \\
478 \\
407 \\
539\end{array}$ & $457 \pm 102$ \\
\hline 2 & 低 & 蛋 & 白 & $\begin{array}{l}\hat{\partial} \\
\vartheta\end{array}$ & $\begin{array}{l}1 \\
1\end{array}$ & $\begin{array}{l}2 \\
2\end{array}$ & $\begin{array}{l}5.0 \\
5.8 \\
4.0 \\
6.1\end{array}$ & $5.25 \pm 1.49$ & $\begin{array}{r}10.6 \\
6.4 \\
8.0 \\
8.6 \\
\end{array}$ & $8.40 \pm 2.76$ & $\begin{array}{l}426 \\
289 \\
371 \\
364\end{array}$ & $362 \pm 89.5$ \\
\hline 3 & $\Sigma$ & $-\quad r$ & ン & $\begin{array}{l}\delta \\
\wp\end{array}$ & $\begin{array}{l}1 \\
1\end{array}$ & $\begin{array}{l}2 \\
2\end{array}$ & $\begin{array}{l}5.4 \\
5.9 \\
6.2 \\
5.8 \\
\end{array}$ & $5.83 \pm 0.52$ & $\begin{array}{l}9.6 \\
8.9 \\
5.9 \\
6.6 \\
\end{array}$ & $7.76 \pm 2.82$ & $\begin{array}{l}212 \\
356 \\
374 \\
480\end{array}$ & $380 \pm 200.5$ \\
\hline 4 & 新 & 生 豆 & 噟 & $\begin{array}{l}\hat{o} \\
\text { o }\end{array}$ & $\begin{array}{l}1 \\
1\end{array}$ & $\begin{array}{l}2 \\
2\end{array}$ & $\begin{array}{l}5.1 \\
5.3 \\
5.5 \\
5.5\end{array}$ & $5.35 \pm 0.30$ & $\begin{array}{l}8.4 \\
9.6 \\
5.6 \\
6.0 \\
\end{array}$ & $7.40 \pm 2.90$ & $\begin{array}{l}324 \\
440 \\
540 \\
579 \\
\end{array}$ & $470 \pm 181.4$ \\
\hline 5 & 豆 & の & 花 & $\begin{array}{l}\delta \\
\wp\end{array}$ & $\begin{array}{l}1 \\
1\end{array}$ & $\begin{array}{l}2 \\
2\end{array}$ & $\begin{array}{l}5.8 \\
5.7 \\
5.9 \\
6.7\end{array}$ & $6.02 \pm 0.72$ & $\begin{array}{l}7.6 \\
6.2 \\
5.6 \\
5.9\end{array}$ & $6.33 \pm 1.30$ & $\begin{array}{l}345 \\
322 \\
541 \\
696\end{array}$ & $476 \pm 280.9$ \\
\hline $\begin{array}{l}\rho \\
6\end{array}$ & 脱 & 脂 粉 & 乳 & $\begin{array}{l}\delta \\
f\end{array}$ & $\begin{array}{l}1 \\
1\end{array}$ & $\begin{array}{l}2 \\
2\end{array}$ & $\begin{array}{l}6.1 \\
6.0 \\
5.2 \\
5.4\end{array}$ & $5.67 \pm 0.70$ & $\begin{array}{l}7.2 \\
9.6 \\
4.2 \\
4.8\end{array}$ & $6.47 \pm 3.89$ & $\begin{array}{l}411 \\
387 \\
457 \\
781\end{array}$ & $509 \pm 292.2$ \\
\hline
\end{tabular}


䁍重量を合計した価についてみると，群，性，腹など すべてに有意差が認められる。群別の平均値については 低蛋白群が最す小さく新生豆腐群と s.m. 群がこれにつ ぎこれら 3 群の間には有意差は認められないが低蛋白群 は基本 $(\mathrm{P}<0.01)$, ミートン $(\mathrm{P}<0.001)$ および豆の花 $(\mathrm{P}<0.02)$ の各群よりそれぞれ有意差で小さい。ミート ン群は他のすべての群より有意差で最も大で（基本群と の差は $\mathrm{P}<0.01$, 他はすべて $\mathrm{P}<0.001)$, 基本群がこれに つぎ同様に他の群より有意差で大である。(豆の花群との 差 $\mathrm{P}<0.05$, 新生豆腐扰よびs. $\mathrm{m}$. 群との差 $\mathrm{P}<0.01$ )。

(4) 骨の長さ, 重さおよびカルシウム量 : 右側大腿骨 および脛骨・腓骨の長さ, 重さ扰よび重量当りの骨カル シウム量は表 9 に示す通りである。骨の長さでは腹別に 2 の腹は 1 の腹より長く $(\mathrm{P}<0.02)$, 骨の重さでは性 別に雄は雌より重く（P<0.01）共に有意差を示すが, 群別の平均値ではいずれも低蛋白群が最も小さく, 基本 群がこれにつぎ， 3 大豆慗品㧊よび s.m.の各群が上位 を占める傾向を示すがすべて有意差は認められない。骨 重量に対する骨カルシウム量は群別の平均値に有意差が 認められ新生豆腐群が最も大で, 基本, 低蛋白およびミ ートンの 3 群より有意差 $(P<0.05)$ を示すが, 豆の花 および s.m. 群との間には差が認められない。またミ一 トン群以外の各群の間にもそれぞれ有意の差は認められ ない。

(5) 血清蛋白, 血清Al·P-ase A. および肝X. O.A： これらの測定值を表10に示す。血清蛋白は群別, 性別お よび腹別にすべて有意の差は認められないが，群別に低 蛋白群が最も小さい値を示している。血清 $\mathrm{Al} \cdot \mathrm{P}$-ase 活 性度は性別に有意差が認められ雄は雌より高い（ $\mathrm{P}<$ 0.02)。群別の平均值に有意差は認められないが, 他の 測定值と逆に低蛋白群が最も高い値を示している。肝 X O.A.は血清 $\mathrm{Al} \cdot \mathrm{P}$-ase A. と同棁に性别の平均値にの 因 3 血清AI.P-ase A. と肝X.O.A. との相関

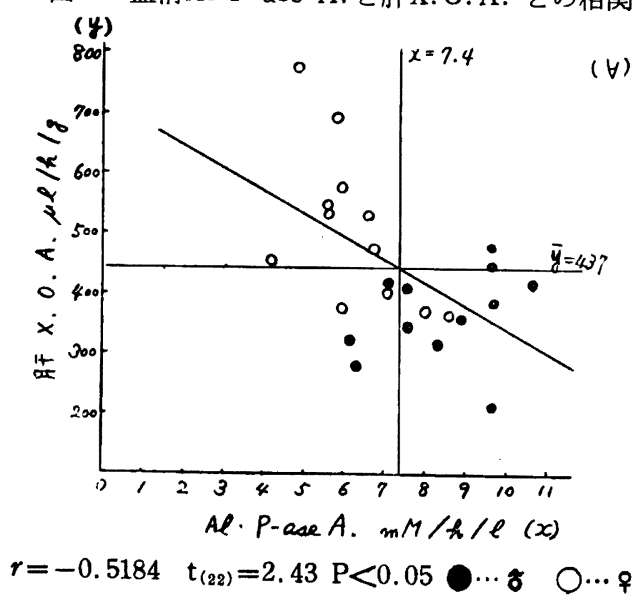

(312)
み有意差が認められ，Al·P-ase とは逆に雄は倠より低 く（P<0.01）また有意差ではないが低蛋白群が取も低 い傾向を示している。血清Al.P-ase A. と肝X.O.A. との相関々係をみると図 3 に示すよ5に雨者の間には有 意の逆相関々係が認められ（P<0.05）血清 $\mathrm{Al} \cdot \mathrm{P}$-ase A.の高い場合は肝X.O.A.が低い。

\section{総括および考察}

厚生省国民栄美調査成績昭和35年度生産者世帯の主な 蛋白給源食品より構成される食慨を基本食とし，これよ り動物蛋白食品を除いたものを低蛋白食とし，この低蛋 白食に基本と蛋白含量が同じになるように 3 大豆加工食 品を添加したものをそれぞれミートン食, 新生豆腐食, 豆 の花食とし，比較のため同様に脱脂粉乳(s.m.) を加え たすのをs.m. 食とし以上合計 6 食群について rat によ る発育試験を行なったところ次のような結果を得た。な お肪肪，灰分，ビタミンなどは充分な量を補給した。

（1）体重增加率は群別の平均値に有意の差は認められ ないが, 低蛋白群が最も少なく, 基本がややこれを上迴 り，3大豆製品および s.m. 群は一様にさらにこれを上佪 っている傾向がみられる。すし実験動物の数が各群雌雄 3 匹ずつ合計36匹以上になると，低蛋白群は有意差で 3 大豆製品扰よび s.m. 群より劣ることとなる。この点か ら動物実験の場合は最小限 1 群雌雄 6 匹を用いることが 望ましく，また性別, 腹別に有意差が認められるので, 性扣よび腹の条件も考虑することが望ましい。

（2）飼料効率は有意差で雌は雄より悪く，また有意差 ではないが低蛋白群が最も効率が悪い傾向が見られる。

（3）蛋白含有率が最も低く，かつ款類からの蛋白か380 \%を占める低蛋白群の，蛋白効弯が他の 5 群（動蛋また は大豆蛋白が33～43\%, 殼類蛋白が43～53\%）上りも有意 差で大きい。体重增加が必ずしも体蛋白の增加と比例せ ず, 体脂肪の增加による場合があるとして, 蛋白の栄養価 判定法としての蛋白効率の欠点が指摘されていることを 示すものと考元る。一方動物蛋白を $33 \%$ 含む基本群およ びミルク蛋白を $42 \%$ 含む s.m. 群とこれらの動物蛋白の 代りに大豆蛋白を用いた 3 大豆製品群との蛋白效率には すべて有意差が認められなかったことは, 蛋白含有率が ほほ等しい場合, これら大豆蛋白の利用価をある程度肯 定できるものと考える。

（4）内臓の重量: 脾蔵を除き肝臓と腎臟では群別の平 均值に有意差の認められる場合すあり, 特に低蛋白群は 最す小さく, 最も大きいミートン群との間に有意差が詺 められる。また 3 内臓を合計してみてす，低蛋白群は有 意差で基本, 豆の花拉よびミートン群より小さく内滕発 育に於いて劣るとも考えられる。 
(5) 骨の長さ，重さおよびカルシウム量：骨の長さ， 重さについては群別の平均値に有意の差は認められない が，共に低䖵白群が最す小さく，基本群がこれにつぎ， 3 大豆慗品扰よび s.m.群はほ伊同様の值を示している。 骨の重量当りの $\mathrm{Ca}$ 量は， $\mathrm{Ca}$ 強化がしてある新生豆腐 群が他の群より大で特に基本, 低蛋白拉よびミートンの 3 群との間には有意差が認められる。

（6）血清蛋白，血清 Al·P-ase A. および肝X.O.A.： 血清蛋白量は各群の平均値に有意差は認められなかった が，低蛋白群が最も少ない傾向を示していた。血清 Al. P-ase A. については群別の平均値に有意の差は認めら れないが他の諸測定値と逆の傾向が見られ，低蛋白群が 最も大となっている。血液成分の化学的測定が栄盖状態 判定法の一つとして用いられるよ5になり $\left.{ }^{11}\right), \mathrm{Al} \cdot \mathrm{P}$-ase 虫佝藪病その他骨に於ける異常代謝によって起こる多く の病気の場合血清中に增加するので CaやV. DK関する 栄美状態の判定を与えるものとして測定されているが， Guzman $^{12)}$ らはCentral America の学童の Al.P-ase 值は同年令のアメリカ合衆国の栄養の良い児童に比べる と低いと報告している。一方 Tuba ${ }^{13)}$ らは適当に栄養を とっている成熟白ratの血清 $\mathrm{Al} \cdot \mathrm{P}$-ase 值は食餌中の蛋 白質を貿的または量的に変えてる変化することはないと いっている。また蛋白の利用状態判定の一方法として用 いられる肝X.O.A.については A1·P-ase との間に有 意の逆相関々係が認められ, 諸测定値と同様低蛋白群が 最す小さい傾向を見せ農村低蛋白食の質的量的欠陷を示 すすのと考える。

結語

動物蛋白を含まない低蛋白毞村食慨に，蛋白給源食品 としてミートン, 新生豆腐および豆の花の 3 大豆加工品 を補給した場合の効果を知る目的で rat に上る発育試 锒を行なった。厚生省国民栄養調査昭和35年の生産者世 帯の食品粠成による食慨を基本食とし（蛋白含有率 $11 \cdot 1$ \%,動蛋比33\%)これより動物蛋白給源食品を除いたるの
を低蛋白食とし，これに基本食と蛋白含有率が同じにな るよ5に， 3 大豆加工食品扣よび脱脂粉乳を加えたもの を試験食とした。諸測定値の中には有意の差の認められ ない場合もあったが，低蛋白膿村食慨群は，血清、A1. P-ase A. 拉よび蛋白效率を除き, 飼料効率, 体重增加 率, 骨重量および長さ, 骨カルシウム量, 内臓重量, 血清 蛋白量拉よび胙 X.O.A.などの諸測定值に於いて一様 に最下位を占めていた。また肝X.O.A.と血清 Al.Pase A. との間には有意の逆相関関倸がみられた。基本食 の動物蛋白給源食品の代りに，前記 3 大豆加工品を加え ると（脂肪，灰分ビタミンなどが充分な場合)共に動物 蛋白含有食慨に優るとも少らない良い結果を得たので， これら 3 大豆加工品の利用は宸村の食生活改善に役立つ ものと考えるがなお実験を重ねて検討したい。

本研究は東北大農学部有山教授を代表とする昭和 37 年 度文部省科学研究綜合研究費によるもので，rat の解剖 などについて御援助いただいた東北大医学部高橋教授, ならびに脱脂粉乳，新生豆腐を寄贈された雪印乳業 K.K. および保健産業 K. K. に厚く御礼申し上げます。また豆 の花は東北大医学部近藤名誉教授より御恵与いただいた もので併せて感謝申し上げます。

$$
\text { 文献 }
$$

1) 近藤 : 久留米医学会雑誌, 15, 1(1951)

2) 金田: 東北医学雑誌, 65, 418 (1962)

3) 鷹觜：栄盖と食糧, 13,338 (1961)

4) 林 : 栄盖と食糧, 13,297 (1961)

5 ) 稲垣: 栄盖と食糧, 14, 487 (1962)

6) 岩尾 : 栄養学雑誌, 20,115 (1962)

7) 稲垣: 栄盖と食糧, 14, 487 (1962)

8) 佐藤: 第16回日本栄盖・食糧学会総会発表 (1962)

9 ) 中川 : 栄羔学実験書, p.677, (朝倉書店) (1955)

10) 松村: 農化, 28,984 (1954)

11) E.S. Eppright : J.Nutr., 54, 557(1954)

12) M.A. Guzman : Am.J.Clin.Nutr., 9, 164 (1961)

13) J. Tuba et a'l.: Can.J.Med. Sci., 30, 378(1952)

（東北大学川内東分校家政科） 